(C) 2019 Gembaruk. This article is distributed under the terms of CC Attribution-Share Alike 4.0 International as described at https://creativecommons. org/lice-nses/by-sa/4.0

UDC: 378.018.8: 373.5.011.3-051: 811' 111

\title{
EFL TEACHERS TRAINING IN PAVLO TYCHYNA UMAN STATE PEDAGOGICAL UNIVERSITY: METHODOLOGICAL ASPECT
}

\author{
Alla Gembaruk \\ Ph.D. in Education, Associate professor, \\ Pavlo Tychyna Uman State Pedagogical University, Uman, Ukraine \\ https://orcid.org/0000-0001-8135-0800; e-mail gembaruk.alla@gmail.com
}

The article describes the peculiarities of EFL teacher training in Pavlo Tychyna Uman State Pedagogical University which is done within the framework of new PRESETT Curriculum on Methodology designed in context of 'New Generation School Teachers' joint project, initiated by the Ministry of Education and Science, Ukraine and the British Council, Ukraine. The article highlights the innovative character of the Curriculum and provides its detailed analysis in terms of content, structure, modes of teaching and learning, assessment specifications. The content of the new PRESETT Curriculum on Methodology is described in correlation with the competencies students will get in the result of their learning a particular module. Thus, demonstrating its skill-oriented character and correspondence to the requirements of Ukrainian education reform, the core idea of which is acquiring skills and abilities to obtain knowledge independently and apply it in practice. The article also specifies the way school experience is organized and accentuates its role in EFL teacher training. Such important aspects of the Methodology course as modes of teaching and learning and assessment specifications are dealt with in the article. The effectiveness of the PRESETT Curriculum in EFL teacher training is evaluated by means of survey and focus group discussion where the participants were methdology teachers and students of Pavlo Tychyna Uman State Pedagogical University. The results of the survey and focus group discussion are presented in the article.

Key words: EFL teacher training, PRESETT Curriculum on Methodology, 'New Generation School Teachers' project, school experience, modes of teaching and learning, assessment specifications

Стаття описує особливості методичної підготовки студентів, майбутніх учителів англійської мови, в Уманському державному педагогічному університеті імені Павла Тичини, яка здійснюється за новою методикою навчання англійської мови, розробленою $b$ рамках спільного проекту Міністерства освіти і науки Украйни та Британської Ради в Украйні «Шкільний 
вчитель нового покоління». Подано детальний аналіз Програми на рівні змісту, структури, методіВ навчання та оцінюъання. Опис змісту Програми здійснено через призму компетентностей, якими мають оволодіти студенти по заверченню вивчення конкретного змістового модуля. Тим самим підкреслено компетентністно-орієнтований зміст навчання та його відповідність вимогам освітнъої реформи в Украйні. В статті деталізовано особливості організачії педагогічної практики $b$ школі, яка інтегрована $b$ курс методики, та підкреслено ї̈ роль у практичній підготовиі майбутнъого вчителя англійсъкої мови. Окреслено особливості методіВ навчання та оцінювання студентів, які є інноваційними та відмінними від традиційних підходів. У статті подано результати дослідження ефективності нової методики навчання англійсъкої мови у підготовиі майбутніх учителів, які отримані у результаті бесіди з викладачами методики навчання англійської мови та анкетування студентів Умансъкого державного педагогічного уніВерситету імені Павла Тичини.

Ключові слова: підготовка учителів англійсъкої мови, програма додипломної методичної підготовки майбутніх учителів англійсъкої мови, проект «Шкільий Вчитель нового покоління», педагогічна практика, методи навчання й учіння, методи очінюъання

Introduction. Ukraine's joining the European and the world educational space has brought fundamental changes in the national education system. But the last five years have been the most crucial for the system since important new laws have been passed: on Higher Education in 2014, on Research and Scientific Activity in 2015, and the «Law on Education» in 2017. The New Ukrainian School, which started on September, 1 2018, brought into action the long awaited education reform. The system of pre-service teacher training (PRESETT) in Ukraine has been turned into innovative environment since these laws were put into effect. In this context the Ministry of Education and Science of Ukraine in collaboration with the British Council Ukraine initiated in 2013 the «New Generation School Teacher» joint project. The overall aim of the project was to introduce change in the initial teacher training system of Ukraine through designing and implementing a new PRESETT Curriculum on Methodology for the initial EFL teacher training system in Ukraine. The Curriculum was designed by the project team consisting of 13 university teachers representing the following 8 Ukrainian higher education institutions: Vinnytsia State Pedagogical University (Olena Zmievska); Zhytomyr State University (Larisa Kalinina, Inna Samoylyukevych); Melitopol State Pedagogical University (Tetiana Konovalenko, Olga Goncharova); Nizhyn State University (Olena Taran); Zakarpattia National University (Igor Romanyshyn); Uman State Pedagogical University (Oksana Zabolotna, Alla Gembaruk, Olena Bevz); Kharkiv National Pedagogical University (Natalia Tuchina, Igor Kamynin); Chernivtsi National University (Kateryna Kurysh). The project was done under the consultancy of Rod Bolitho, academic director (Nile Norwich, UK) and Oleksandr Shalenko, teacher/ trainer trainer (Ukraine). The designing of the Curriculum was preceded by the baseline study (2013-2014), which proved the necessity for change in pre-service 
teacher training; and study visits to University of Modern Languages (Tashkent, Uzbekistan), 2013 and Norwich Institute of Language Education (Norwich, England), 2014. These visits gave the possibility to observe and study the best practices of EFL Teaching Methodology (Bevz O. P., Gembaruk A. S., Zabolotna O. A., 2018). So, the new PRESETT Curriculum on Methodology was designed taking into account the results of the baseline study and study visits to Great Britain and Uzbekistan. Being based on the best Ukrainian and world practices in EFL teacher training, the new Curriculum represents a significant change in the way English teachers are educated. The Curriculum piloting (2016-2019) embraced 14 Ukrainian universities and 5 pedagogical colleges participating. Pavlo Tychyna Uman State Pedagogical University was one of them.

Thus, the aim of the article is to analyse EFL teacher training in Pavlo Tychyna Uman State Pedagogical University within the framework of new PRESETT Curriculum on Methodology and to evaluate its effectiveness in EFL teacher training. The aim may be realized by applying the corresponding methods: analysis to gain a better understanding of the Curriculum; focus groups and survey to evaluate the effectiveness of the Curriculum in EFL teacher training.

The new PRESETT Curriculum on Methodology was analysed in terms of its content, structure, modes of teaching and learning, assessment specifications. The following key findings emerged from the Curriculum analysis. The Curriculum consists of 6 modules. Each module represents a broad area of methodology, and contains a number of units, 22 in all. Each unit covers an essential specialist topic for English teachers in training (see Table 1).

Table 1

The content of the new PRESETT Curriculum on Methodology

\begin{tabular}{l|l|l}
\hline \multicolumn{1}{c|}{ Module } & \multicolumn{2}{|c}{ Unit } \\
\hline \multirow{2}{*}{$\begin{array}{c}\text { ELT Methodology course: } \\
\text { aspects and tools. }\end{array}$} & \multicolumn{3}{|c}{ Values and beliefs about learning and teaching } \\
\hline \multirow{2}{*}{$\begin{array}{l}\text { 1. Understanding } \\
\text { Learners and Learning }\end{array}$} & 1.1 & Psychological Factors in Language Learning \\
\cline { 2 - 3 } & 1.2 & Second Language Acquisition \\
\cline { 2 - 3 } & 1.3 & Developing Learner Autonomy \\
\hline \multirow{2}{*}{ 2. Preparing to Teach 1 } & 2.1 & Principles of Communicative Language Teaching \\
\cline { 2 - 3 } & 2.2 & Teaching Grammar in Context \\
\cline { 2 - 3 } & 2.3 & Teaching Vocabulary in Context \\
\cline { 2 - 3 } & 2.4 & Classroom Management \\
\hline \multirow{4}{*}{ 3. Preparing to Teach 2 } & 3.1 & Language Skills - Teaching Listening \\
\cline { 2 - 3 } & 3.2 & Language Skills - Teaching Speaking \\
\cline { 2 - 3 } & 3.3 & Language Skills - Teaching Reading \\
\cline { 2 - 3 } & 3.4 & Language Skills - Teaching Writing \\
\hline \multirow{4}{*}{ 4. Preparing to Teach 3 } & 4.1 & Planning Teaching \\
\cline { 2 - 3 } & 4.2 & Working with Materials \\
\cline { 2 - 3 } & 4.3 & Error Analysis and Dealing with Errors \\
\cline { 2 - 3 } & 4.4 & Testing and Assessment \\
\hline
\end{tabular}


Continuation of table 1

\begin{tabular}{l|l|l}
\hline 5. Specialised Dimensions & 5.1 & Classroom Investigation 1 \\
\cline { 2 - 3 } & 5.2 & Teaching Young Learners \\
\cline { 2 - 3 } & 5.3 & Catering for Special Educational Needs \\
\cline { 2 - 3 } & 5.4 & Developing Intercultural Competence \\
\cline { 2 - 3 } & 5.5 & $\begin{array}{l}\text { Information and Communication Technology } \\
\text { (ICT) in Learning and Teaching English }\end{array}$ \\
\hline $\begin{array}{l}\text { 6. Professional } \\
\text { Development }\end{array}$ & 6.1 & Classroom Investigation 1 \\
\cline { 2 - 3 } & 6.2 & $\begin{array}{l}\text { Planning for Continuing Professional } \\
\text { Development }\end{array}$ \\
\hline
\end{tabular}

To better understand the content of the new PRESETT Curriculum on Methodology presented in Table 1 we decided to correlate each of the modules with the competencies students will get in the result of their learning. The Curriculum starts with the introduction to the whole course which gives students the general understanding of the curriculum in terms of its content and structure, methods of teaching, assessment specifications.

As a result of learning on the module «Understanding Learners and Learning», students will demonstrate the ability to reflect on their own language learning process; identify ways of encouraging acquisition in addition to learning in the classroom; give recommendations to a group of learners on how to plan, organise and take control of their own learning according to their learning styles. Module 2 «Preparing to Teach 1» is focused on developing such abilities as ability to identify features of different approaches and methods in classroom materials and procedures; choose appropriate strategies and select activities for teaching grammar and vocabulary in context; analyse classroom events with attention to organisation, modes of interaction, classroom language, classroom resources; use classroom language appropriate to age and learning needs; reflect on their learning on the module.

The module «Preparing to Teach 2» deals with teaching language skills: listening, speaking, reading and writing. As a result, students will be able to identify problems which learners may face in developing receptive and productive skills; analyse a skill-oriented piece of teaching material and define its purpose; select authentic texts for listening and reading and design activities for different learning purposes; design a sequence of activities focusing on developing productive skills according to learners' needs; plan a sequence of activities which integrate listening, speaking, reading and writing skills; reflect on their learning on the module.

Module 3 «Preparing to Teach 3» is designed to equip future EFL teachers with fundamentals of lesson planning, selection, adaptation and supplementation of materials, ways of dealing with errors and assessment. The level of grasping the key issues of the modules will be checked by students' ability to design a lesson plan for use with a specific group of learners; evaluate a course book for a specific learning/ teaching context; select existing tests to assess learners' progress and achievement; design new tests to assess learners' progress and achievement; assess and evaluate 
learners' reading, listening, speaking and writing skills using set criteria; identify different types of errors in learners' spoken and written language and deal with them appropriately; reflect on their learning on the module.

Module 5 «Specialised Dimensions» includes particular aspects of language teaching. Ability to plan, carry out, report on and make use of the results of a small scale classroom investigation; choose teaching strategies, methods, materials and assessment tools appropriate to young learners; evaluate, select and adapt materials and Internet resources to teach language to learners with different learning needs; choose teaching strategies, methods and assessment tools to teach language to learners with different learning needs; design activities to develop cultural awareness in learners; make appropriate use of ICT in teaching and learning; reflect on their learning on the module is supposed to be demonstrated by the students as the results of learning on this module. The last module «Professional Development» is aimed at developing students' ability to plan their continuous professional development (Core Curriculum English Language Teaching Methodology: Curriculum Map).

As can be seen from the brief description of the competencies students will get in the result of their learning on each of the modules, the content of the new PRESETT Curriculum on Methodology is skill-oriented. Thus, it meets the requirements of Ukrainian education reform, the core idea of which is acquiring skills and abilities to obtain knowledge independently and apply it in practice.

One more aspect that proves the competence-based content of the Curriculum is school experience. Being an integral part of the EFL teacher training, it is introduced in all three years of the course delivery, providing a direct link between methodology classes and teaching at school. Thus, trainee students have an opportunity to develop their teachers' competence in the classroom context within school settings. School experience is well-structured and ensures students' gradual entering the profession from guided observation (semesters 3 and 4) through teacher assistantship (semesters 5, 6 and 7) to observed teaching (semester 8). Table 2 provides the general understanding of the way school experience is organized.

Table 2

The organization of school experience

\begin{tabular}{c|l|l|l}
\hline \multirow{2}{*}{ Semester } & \multicolumn{1}{|c|}{ Module } & \multicolumn{2}{c}{ School experience } \\
\cline { 3 - 4 } & & \multicolumn{1}{c}{ Stage } & \multicolumn{1}{c}{ Frequency } \\
\hline 3 & $\begin{array}{l}\text { 1. Understanding } \\
\text { Learners and Learning }\end{array}$ & Guided observation & Once a fortnight \\
\hline 4 & 2. Preparing to Teach 1 & Guided observation & Once a fortnight \\
\hline 5 & 3. Preparing to Teach 2 & Teacher assistantship & Once a week \\
\hline 6 & Preparing to Teach 3 & Teacher assistantship & Once a week \\
\hline 7 & Specialised Dimensions & Teacher assistantship & 5 once a week \\
\hline 8 & $\begin{array}{l}\text { Professional } \\
\text { Development }\end{array}$ & Observed teaching & 6 weeks full time \\
\hline
\end{tabular}


During guided observation, students have an opportunity to observe experienced teachers at work and to make connections with their learning during the first year of the methodology course. During teacher assistantship, students not only observe lessons and generally support English language teachers but plan lessons together with their mentors and even try their hand at teaching parts of a lesson. During observed teaching, which lasts for 6 weeks, students perform the role of a teacher under the supervision of school mentors and university tutors. All the stages of the school experience are supplied with specially designed observation tasks that cover the content of each of the units. So, students know what is required of them during school experience and how they will be assessed.

According to the PRESETT Curriculum teacher training starts in Year 2 and lasts for three years. The total number of hours allocated to the whole course is 660 , where 396 hours are contact and the rest 264 hours are self-study. That makes the methodology course a core subject in EFL teacher education. Since methodology is delivered in English, it promotes the development of language proficiency level as well as the level of professional communication. Besides, students undertake school practice throughout the whole methodology course. The Curriculum specifies a total of 17 credits for school experience. The frequency of school experience depends on its type. So, guided observation takes place once a fortnight (one full day of at least 4 class hours) throughout Year 2. Teacher assistantship takes place once a week. Thus, students spend one day (minimum 4 hours) in classes at school with no classes timetabled at the university. During observed teaching students spend six weeks full-time in schools (Core Curriculum English Language Teaching Methodology: School Experience). Another distinguishing feature of the PRESETT Curriculum is approaches to teaching and learning. Having refused from lecturing as an inefficient way of delivering content, new methodology relies on innovative teaching and learning approaches including task-based learning, the use of case studies, simulations, group projects and problem solving. All of these approaches are intended to promote high levels of interaction and student involvement in their own learning processes (Core Curriculum English Language Teaching Methodology: Rationale).

Assessment in the Methodology Curriculum is of two types: continuous and final. Continuous assessment is done by the methodology teacher at the end of each unit within the module. Its main aim is to evaluate how successfully students achieved the learning outcomes. Assignment types vary from unit to unit. Among the assignment types are essays, reflective writing, report presentations, quizzes, lesson plans, case study materials, test design, a professional development plan, portfolio, etc. Students are given grades according to the detailed criteria in the assessment specifications for each unit in the Curriculum. At the end of the course, all the scores for unit assignments are averaged to yield a final grade. Final assessment is carried out at the end of the methodology course. Its aim is to evaluate how successfully a student achieved the learning outcomes of the whole Curriculum. Final assessment is based on three components: average score achieved in all module assessments (30\%) Observed teaching (40\%) Qualification paper (30\%). Each component is assessed separately according to different criteria. To pass the Methodology course, students must be successful in all of the three components (Core Curriculum English Langua- 
ge Teaching Methodology: Assessment). The analysis of the new PRESETT Curriculum on Methodology has proved its innovative character in terms of its content, structure, modes of teaching and learning, assessment specifications. Being skilloriented, it meets modern education requirements and promotes the development of new generation school teacher, able to think critically, to express and defend his or her point of view, to make decisions; a teacher, ready to implement changes in school which is very important in the framework of «The New Ukrainian School» reform.

According to the Order of Ministry of Education and Science Ukraine «On Conducting a Pedagogical Experiment on the Methodological Training of Trainee Teachers of English» (№ 871 issued on August 12, 2015) the implementation of the new PRESETT Curriculum on Methodology at the Faculty of Foreign Languages in Pavlo Tychyna Uman State Pedagogical University started in September 2016. The Methodology course was introduced as recommended by the Curriculum without any adaptations. All second-year students, 56 in number, took part in the Curriculum piloting, which lasted for three years. The proficient university teachers, who participated in the British Council Ukraine professional development summer and winter schools, were involved in piloting the new Curriculum. As school experience is considered to be an integral part of the Methodology course, the university signed agreements with 11 secondary schools so that students have the possibility to have practice at school under the mentorship of experienced teachers.

To evaluate the effectiveness of the Curriculum in EFL teacher training we referred to the following research methods: survey and focus groups. Survey made it possible to gather large size of information in a short period of time. A total of 56 participants were recruited for the survey. Questionnaire was chosen as survey data collection tool and included three questions and three options for each question. The same questionnaire was given to the students at the beginning of their study the Methodology course in September, 2016 and at the end of its study after the observed teaching, in April, 2019. It was done in order to trace the change in students' attitude to the key aspects of the Curriculum. To analyze the data collected through the questionnaire, a graph was created to represent the result for each question by itself. The results of the questionnaires are demonstrated in Figures 1, 2, 3.

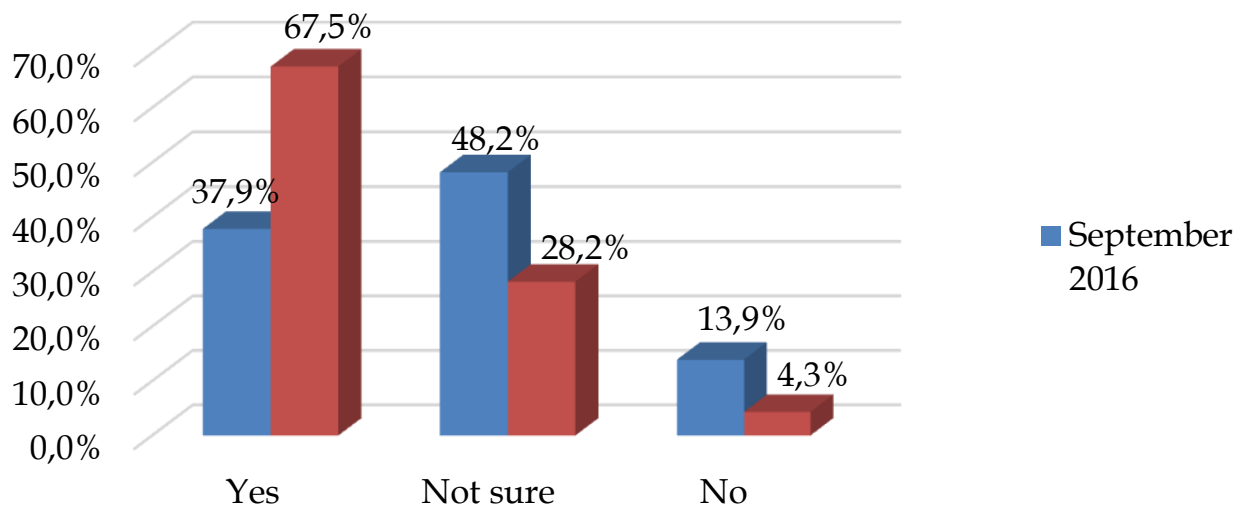

Figure 1. The results of students' responses to the question «Do you plan to work as a teacher at school?» 
Figure 1 illustrates students' intentions to work as teachers at school. What becomes immediately apparent is that the number of those who are willing to work at school has increased by 29,6 percentage points by the end of studying the Methodology course. Contrary, the percentage of those who are still not sure or do not intend to work at school had decreased by $20 \%$ and $9,6 \%$ accordingly. As the majority of students connect their future career with teaching, this suggests that the new Curriculum on Methodology is effective in EFL teacher training.

Figure 2 provides the results of students' responses to the question «What do you consider more important for you in the Methodology course?» From the results displayed in this figure, we can see that students give priority to professional skills considering them more important for them compared to theory. Overall we can see a clear upward trend in a number of those students who consider the development of professional skills more important than theory in the Methodology course while the number of those who give preference to theory or both theory and professional skills has dropped. The percentage of those who have chosen professional skills was 37,0 in September 2016. The percentage point grew up to 54,4 in April 2019. On the contrary the number of those who have chosen theory fell to $2,1 \%$ and the number of those who have chosen both categories fell to 43,5\% in April 2019. So, the results displayed in Figure 2 are in favour of the new Methodology Curriculum which is not theory-oriented but skill-oriented.

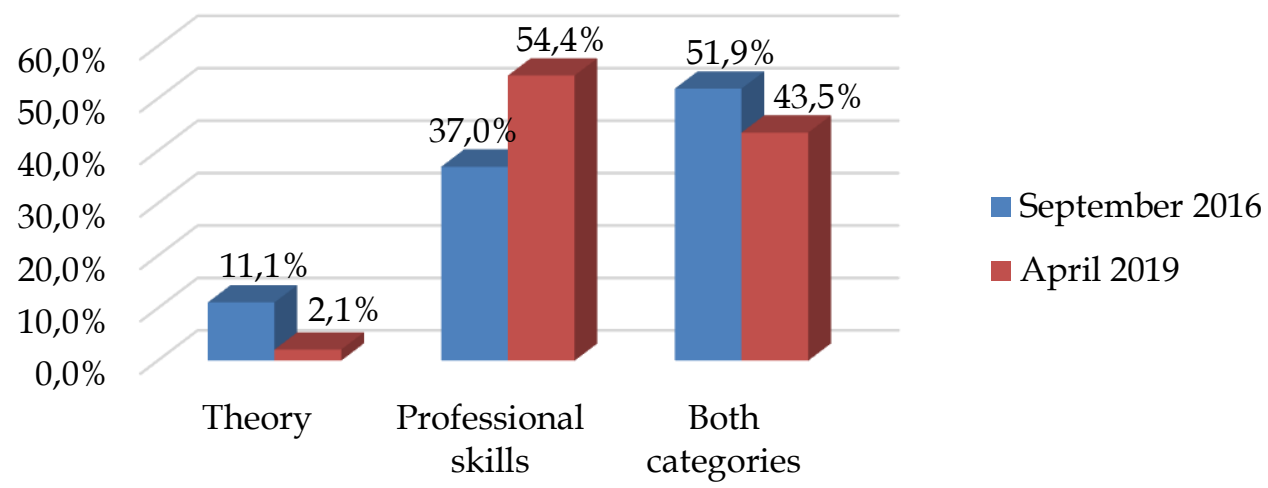

Figure 2. The results of students' responses to the question «What do you consider more important for you in the Methodology course?»

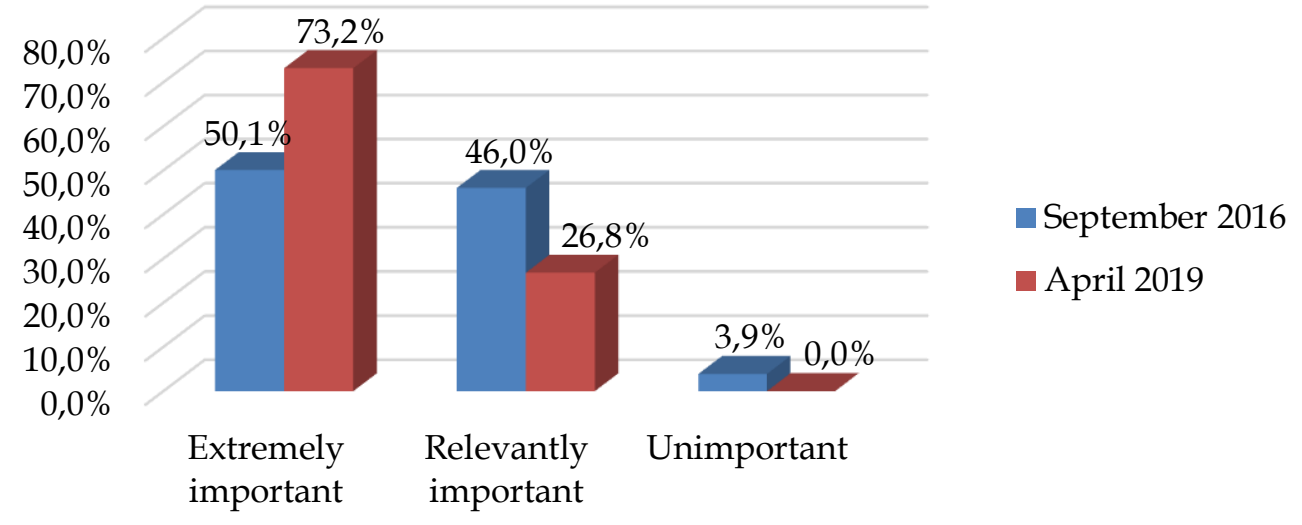

Figure 3. The results of students' responses to the question «How important do you find school experience for you as a perspective EFL teacher?» 
From the results displayed in Figure 3 and the statistical analyses conducted, we can see that no one considers school experience unimportant in EFL teacher training at the end of their studying the Methodology course. Meanwhile, the percentage of those who find school experience extremely important had significantly risen from 50,1\% in September 2016 to 73,2\% in April 2019. The results indicate the justification of the way school experience is organized within the framework of the new Methodology Curriculum.

The survey has shown students' attitude to the key aspects of the Curriculum. More detailed data was collected through focus groups which provided insights into how people think and a deeper understanding of the phenomena being studied (Nagle B., Williams N.). So, the purpose of the focus groups was to find out students' and teachers' perceptions, opinions and attitudes towards the new Curriculum on Methodology. Thus, there were two focus groups involved in the Curriculum evaluation. It gave us the possibility to involve more stakeholders in the evaluation process and look at the problem from two perspectives. The sample for focus group 1 had students of piloting groups. There were 12 of them: 2 representatives from each group. We referred to convenience sampling. So, the sample for a focus group had individuals with characteristics of the overall population, thus contributing to helping the research gain a greater understanding of the topic. The discussion was arranged around the following questions: What are your initial impressions about the Methodology course? What resources are available to you? How do you use them? What are you gaining from your experience of guided observation at school? How do you understand your future role as an English language teacher? The Methodology course is taught in English. What are the advantages and disadvantages of this, from your point of view? Is there anything else we haven't discussed yet that you think is important to mention?

The following key findings emerged from data analyses:

- students feel positive about the Methodology course, find it useful, they consider it to be a completely new experience in their studying; the Methodology course teaches them to communicate to work together;

- students understand their future role as an English language teacher to be a facilitator, motivator, organizer of the learning process;

- for the students English is a $21^{\text {st }}$ century skill, which creates opportunities

- students find a number of advantages in the Methodology course being taught in English: develop skills in English, develop fluency, students are not afraid of making mistakes;

- guided observation is interesting and important, it gives the opportunity to be inside the process, to see how different teachers work; guided observation makes it possible for students to bridge theory and practice, to develop critical thinking, to gain some experience;

- students appreciate that due to guided observation they can find a way with school children, communicate with them, understand how to make teaching their profession. 
Though, the general impression of the Methodology course is quite positive, students mentioned some problematic or challenging issues:

$>$ different level of language proficiency of students sometimes hinders Methodology learning;

$>$ students use handouts, videos, presentations and Internet resources, they want to have books;

$>$ though students find the new Methodology course useful as they learn a lot of new techniques, work with authentic materials, and enrich their vocabulary, at first they had difficulty understanding terminology.

The sample for the focus group 2 had methodology teachers who were implementing the course, and included 5 participants. The discussion was arranged around a set of specially developed questions. These were five open-ended questions: What are your impressions of the new Methodology Curriculum? What do you find beneficial about the course? What do you find challenging and difficult about the course? How satisfied are you by the student outcome performance generated by the methodology course? How effective is the course for implementing key ideas of education reform? Questions were asked in an interactive group setting where participants were free to talk with other group members. The answers were analysed right after the end of the discussion. The key findings were summed up. The report in the bulleted style is presented below:

- teachers' first impressions of the Methodology course are positive and optimistic;

- teachers find the Curriculum up-to-date as it is based on the best European practices;

- in teachers' opinion, the methodology course provides students with important professional skills related to methodology and develops $21^{\text {st }}$ century skills;

- being skill-oriented the Curriculum goes in line with the requirements of the New Ukrainian School reform;

- «to theory through practice» approach is considered very beneficial as it makes students think, develops their creativity. Interactive modes of teaching and learning are viewed beneficial for both teachers and students;

- innovative methods of teaching influence the way students learn, they become more autonomous, more interested, more inspired and more confident; students demonstrate their creativity and ability to think critically, the skills that every modern teacher must have;

- to the positive influence of the methodology course on students' performance, teachers refer the fact that students are not afraid of making mistakes, of expressing their ideas and taking risks. Besides, the language teachers mention that the students of the piloting groups demonstrate much better level of English.

Though the general impressions of the course are positive, teachers pointed out some challenging issues. They find time-consuming to design sessions for a learner-centered classroom following all the requirements. Lack of necessary resources impedes the process of session design. 
In general, focus group discussions provided a deeper understanding of the Curriculum. In-depth data on specific evaluation questions helped to determine Curriculum success and proved its effectiveness in EFL teacher training. The fact that both survey and focus groups revealed the same data confirms that the new Curriculum on Methodology is effective in EFL teacher training.

Conclusions. The new PRESETT Curriculum on Methodology was developed within the framework of the «New Generation School Teacher» joint project initiated and supported by the Ministry of Education and Science and the British Council in Ukraine. Ten Ukrainian universities are already teaching perspective teachers of English according to the new Curriculum. Pavlo Tychyna Uman State Pedagogical University is among them. According to the Curriculum classes are conducted exclusively in English and time is balanced between theory and practice. Content delivery is not based on lectures but on the innovative modes of teaching and learning. Their interactive character promotes collaboration, critical thinking, communication, creativity. School experience is integrated into the Methodology course.

Thus, it gives students opportunity to collaborate with experienced teachers and to learn from them. The recommended assessment tools help to evaluate how successfully students achieved the learning outcomes. The interpreted results of focus group discussions and questionnaire were positive. Thus, they proved the effectiveness of the new Methodology Curriculum in EFL teacher training. Taking all this into account we can state that the new Curriculum represents a significant change in the way English teachers are educated. It goes in line with requirements of the education reform in Ukraine and is worth to be implemented in all the teacher training universities in Ukraine.

\section{References:}

Bevz O. P., Gembaruk A.S., Zabolotna O. A. (2018) Teaching and learning English can be different: introducing new methodology curriculum. Inspiring Professional Excellence in Teaching Languages: proceedings of the IV international spring symposium. Bălți: Indigou Color, 2018, 22-32.

Core Curriculum English Language Teaching Methodology: Assessment. Retrieved from: http://docs.wix static.com/ugd/15b470_fdc26309944f47498b5ac3440544eca6.pdf.

Core Curriculum English Language Teaching Methodology: Curriculum Map. Retrieved from: http:/ / docs. wixstatic.com/ugd/15b470_08101e4aebed4685aa0d10dd7c36d599.pdf.

Core Curriculum English Language Teaching Methodology: Rationale. Retrieved from: http://docs.wix static.com/ugd/15b470_33426fd1525a4d66a4151eee8ae0655e.pdf.

Core Curriculum English Language Teaching Methodology: School Experience. Retrieved from: http:// docs.wixstatic.com/ugd/15b470_4447599f7d584e7b87fcb9c5bc7f5624.pdf.

Nagle B., Williams N. Methodology Brief: Introduction to Focus Groups. Retrieved from: http://www. mmgconnect.com/projects/userfiles/file/focusgroupbrief.pdf. 